\title{
TOWARD UNDERSTANDING TOURIST LANDSCAPE. A COMPARATIVE STUDY OF LOCALS' AND VISITORS' PERCEPTION IN SELECTED DESTINATIONS IN POLAND AND GREECE
}

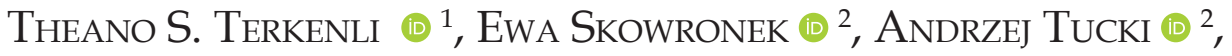 \\ NiKolaOs KounelLis ${ }^{3}{ }^{3}$ \\ ${ }^{1}$ Department of Geography, University Hill, University of the Aegean, Mytilene, Greece \\ ${ }^{2}$ Department of Regional Geography and Tourism, Maria Curie-Skłodowska University, Lublin, Poland \\ ${ }^{3}$ Department of Administration, Business School, University of the Aegean, Mytilene, Greece
}

Manuscript received: January 18, 2019

Revised version: July 24, 2019

\begin{abstract}
Terkenli T. S., Skowronek E., Tucki A., Kounellis N., 2019. Toward understanding tourist landscape. A comparative study of locals` and visitors` perception in selected destinations in Poland and Greece. Quaestiones Geographicae 38(3), Bogucki Wydawnictwo Naukowe, Poznań, pp. 81-93. 7 figs, 7 tables.

AвSTRACT: This paper critically negotiates the concept of the tourist landscape and proceeds, through a comparative cross-cultural empirical study, to test its basic conceptual premises in one upland and one seaside tourist destination, in Central Europe and in the Mediterranean. The conceptualization and employment of the term 'tourist landscape', in the social sciences and beyond, has been mostly intuitive and lacking a rigorous and broad-based conceptualization and empirical verification, incorporating its viewers'/users' perceptions. On the basis of a conceptual model of the tourist landscape, the paper assesses conceptions and perceptions of the 'tourist landscape' and its constituent elements by tourists, locals, and tourism stakeholders in Zwierzyniec, Poland and Chios Island, Greece.
\end{abstract}

KEY WORDS: tourist landscape, conceptualization, perception, Greece, Poland

Corresponding author: Theano S. Terkenli,t.terkenli@aegean.gr

\section{Introduction and theoretical background}

The significance of landscape to the variety of experiences sought through or unfolding at a visited destination is well-established and considered paramount (Urry 1995, Löfgren 1999, Terkenli 2000, 2014, Cartier, Lew 2005, Mikulek 2011). Nonetheless, the great variability, depth and significance of this relationship, in its proper time-space-culture context, largely remains empirically unexplored, especially as regards the role of the landscape in the tourist experience.

Despite its importance, this issue is difficult to analyse, due to its multidimensional nature and the fact that landscape is connected with subjective or collective perceptions, by definition (Council of Europe 2000). Extensive research highlights the great variability and cultural contingency in landscape perception, preference and appreciation, among visitors (Rojek, Urry 1997, Roovers et al. 2002, Conrad et al. 2011, Adevi, Grahn 2012). 
Tourist landscape analysis is also difficult, because of the enormous current proliferation of a broad range of alternative and special-interest forms of tourism, variably (and often, intricately) connected to the visited landscapes. All types of landscapes may potentially hold interest for some type of visitor, for purposes of consumption of goods, services, activities, experiences, etc. (Terkenli et al. 2019). Although much quoted in tourism literature, in most cases, the term tourist landscape has been analysed for different research objectives, in a range of theoretical framings, without providing or building on a more generally-acknowledged definition (see e.g. Chronis, Hampton 2008, Fyhri 2009, Xiaobo 2010, Chrenka, Ira 2011, Kulczyk 2013).

Since the first attempts at its definition (1970s-1990s), the emphasis has shifted from highlighting the functions of a landscape aimed at meeting tourists' needs, to its internal systemic mechanisms, its genesis and contextual and tourism development potential (2000s) (Skowronek et al. 2018). Diverse approaches to the tourist landscape have also been changing. For some, it is a particular physiognomy of geographical environment or tourist space (e.g. Krzymowska-Kostrowicka 1999, Włodarczyk 2009a, Włodarczyk 2009b); for others, an area with its own characteristics resulting from its function (tourism), distinguishing it from other types of landscapes (Kowalczyk, Derek 2010, Myga-Piątek 2012) and yet, for others, a result of cultural landscape transformations related to the development of tourism (Lozato-Giotart 1993, Dietvorst 1998, Kowalczyk, Derek 2010, MygaPiątek 2012). Other definitions also given to the tourist landscape are as follows:

- a natural or natural-anthropogenic system, with potential for tourism function, which generates or can generate tourist movement (Wall in Jafari 1982, Richling 2010)

- an area where tourism has, at least temporarily, a predominant role (Krzymowska-Kostrowicka1999, Richling 2010) or

- an area where tourism development constitutes an important component of the landscape (Richling 2010, Kowalczyk, Derek 2010). Only few publications, however, are of particular analytical significance in constructing the definition of the tourist landscape, based on the operationalization of the main elements that constitute it (Gkoltsiou, Terkenli 2012, Skowronek et al. 2018). The constituent elements of a tourist landscape are such that: a) ascertaining that they define a landscape, b) differentiate it from other types of landscapes, on the basis of its connection to tourism, and c) are amenable and applicable to as broad a range of tourist landscape conceptualizations, as possible. Summing up the points of the preceding discussion, we may conclude as to the following emergent groupings of components/elements of a tourist landscape:

- tourist attractions - including features/elements of the natural and/or cultural environment, as well as events or associations which are the object of tourists' interests, meet their preferences and expectations, and attract them to a given destination

- tourist facilities/services - tourist infrastructure and services, interconnected through their functions and complementarities, designed to make attractions available to tourists, and serving the purpose of satisfying tourist/recreational needs (Kowalczyk, Derek 2010: 18)

- presence of tourists - the presence of tourists and tourist movement/activities, resulting from their interest in a given landscape, change its previous functions into tourist ones - equivalent to or predominant over previous ones.

All of the above elements together constitute the physiognomy of a tourist landscape, differentiating it from the pre-existing landscape (before the development of tourism and featuring all other landscape elements, unrelated to tourism), as well as other types of landscapes, e.g. urban, industrial, rural, or other. We may, therefore proceed to the construction of a simple diagrammatic conceptual model (Fig. 1), linking these elements groupings together, whereby tourist

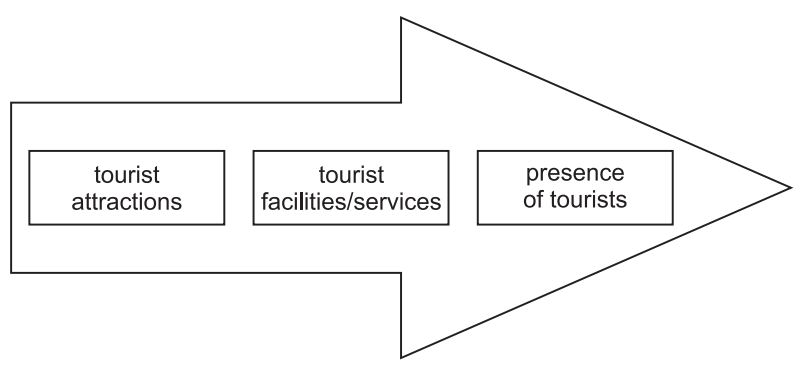

Fig. 1. The model of tourist landscape constituent element groupings. 
attractions (real, imaginary or other) form the basis of all/any tourist interest, and which, when appropriately developed (infrastructure, services etc.), variably attract tourist interest.

Obviously, this is a simplified and generalized conceptualization of the process of tourism development, leading to the creation of tourist landscapes. The latter must always be contextualized in their unique settings, informed by both natu$\mathrm{ral} /$ physical and anthropogenic factors, such as the local communities, landscape physiognomy and various other geographical particularities, in the broader context of the global tourism space/ system (e.g. Włodarczyk 2009b). Furthermore, the processes indicated in this model are not just one-way; as is the case in most tourism models (Pearce 1995), all linkages shown here are reciprocal and multi-directional. Nonetheless, the model purports to stand as a condensed conceptualization of the basic key element groupings turning a landscape into a tourist one (for a more developed discussion on this, see Skowronek et al. 2018). As implied above, a series of other factors play a significant role, here, such as tourists' knowledge/ perceptions/imagination, informed by the tourist industry, the media - including new ICT's and the local supply and tourism management context. All of these factors lead to the creation of a multitude of versions of tourist landscapes, for each of the sides involved, some of which are imaginary. For instance, when referring to the tourists themselves, imaginary tourist landscapes are made up of expectations, feelings and emotions, which accompany the tourist before, during and after the trip. Tourists choose destinations according to their personal goals, interests and preferred forms of activities and experiences. Thereafter, during their stay there, their destination landscapes are contrasted with expectations that had been shaped by social environments and the media, and a final imaginary version of the landscape is formulated through sensual stimuli, experiences and emotions (Terkenli 2014, Norton 1996, Skowronek et al. 2018).

Tourism landscape uses and their impacts on the destination landscape result in its transformation into specific forms and characteristics. For coastal/seaside landscapes especially prone to tourism pressures and environmental, socio-economic and aesthetic impacts, multiple types of damage, including loss of landscape value, have been globally reported, due to urbanization, development and resource degradation (Antrop 1998, Coccossis, Tsartas 2001, Terkenli 2002). In upland/Alpine tourist landscapes (where five types of landscape values have been indicated as central to the tourism experience: scenic, outdoor activities, aesthetic, cultural/ historical and tranquillity), seven categories of threats have also been identified: urbanization, lack of maintenance, congestion, visual/acoustic disturbance, pollution, overuse and traffic (Scolozzi et al. 2014). However, not enough research has so far been conducted cross-culturally and cross-contextually, in order to elucidate and analyse variability both in the holistic conceptualization/construction of tourist landscapes and in their tangible and intangible constituent elements, from all main sides involved. Our goal, then, is to attempt to contribute to such research, broadly speaking, which may serve as a basis for subsequent tourist landscape analysis and investigation into the mechanisms informing such landscapes, as well as into the impacts of tourism on destination landscapes (Terkenli et al. 2019).

Our hope, therefore, is that our proposed conceptual framework (model) and the findings from its empirical application will constitute a useful tool in future planning/management and appraisal/assessment of the state of tourist landscapes, in different settings. Identifying the contribution of the specific landscape elements and properties to the definition and formulation of tourist landscapes will aid in the determination of tourist landscape functionality (preferences of various stakeholder groups involved), sustainability (natural environmental capacity, preferred forms of tourism), and measurability (demand and supply prices, levels of tourism development in the region).

Towards this goal, then, this paper critically negotiates the notion of the tourist landscape and proceeds, through an empirical study, to test its basic conceptual premises, in two different types of tourist destinations, one upland tourist destination in Central Europe and one seaside tourist destination, in the Mediterranean. These were selected as fairly typical mid-range tourist destinations, quite significant mainly for local, regional and (in the case of Chios) also national tourism. As tourist destinations go, they are certainly considered relatively small, by global tourist 


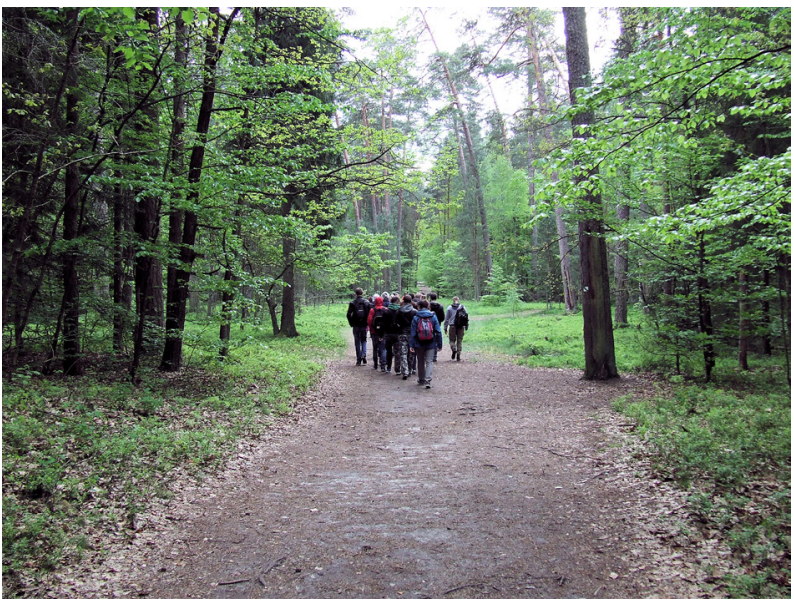

Fig. 2. Zwierzyniec, Poland. The educational path to Bukowa Góra Reserve (Photo: E. Skowronek).

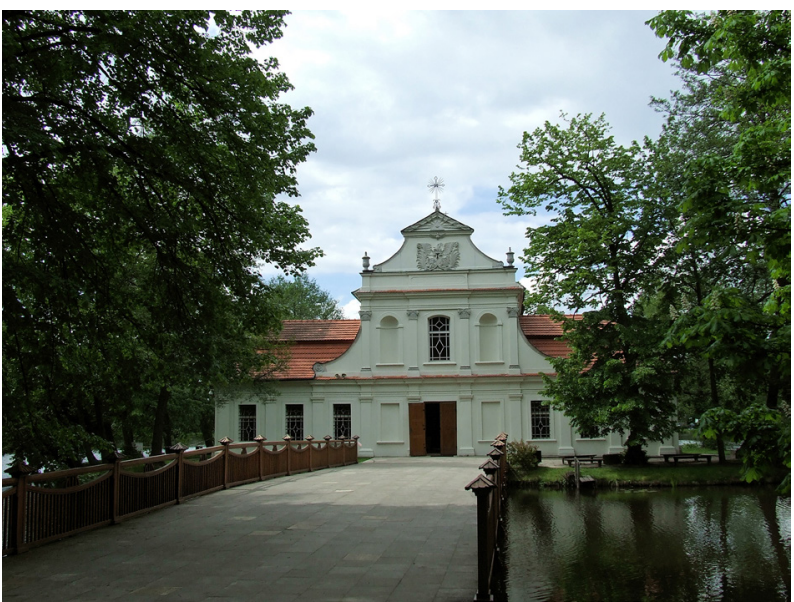

Fig. 3. Zwierzyniec, Poland. The baroque church of St. John of Nepomuk (Photo: E. Skowronek).

industry terms, and far from saturated. They are both rather commonplace smaller European destinations, not fully developed, but highly dependent on their attractive landscapes. They differ in that, although they both cater to tourists seeking quiet, nature-oriented (beach or upland/ forest) activities and amenities, their tourist attractiveness is rooted in very different types of landscapes (Figs 2-5). In order to test the authors' conceptualization of the tourist landscape, this paper assumes a comparative cross-cultural investigation of conceptions and perceptions of the tourist landscape by the main sides involved: tourists, locals, and tourism stakeholders/businesses in the town of Zwierzyniec, SE Poland and Chios Island, Greece. Furthermore, it investigates the significance of landscape elements in these parties' definitions and conceptualizations of what constitutes a tourist landscape. Due to the

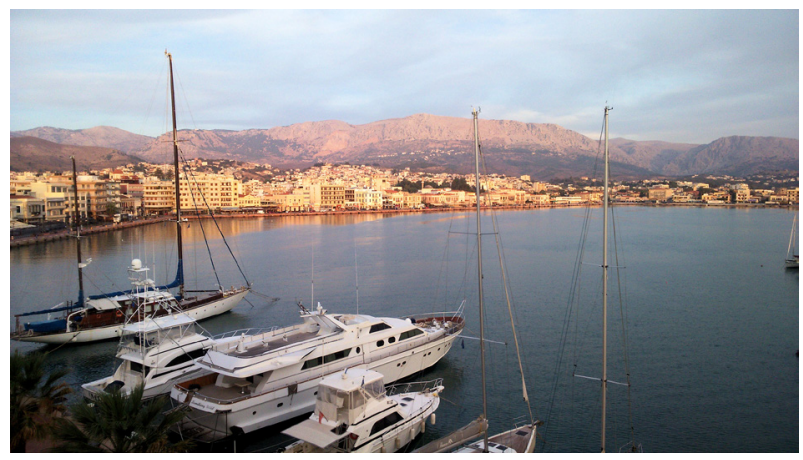

Fig. 4. Chios Island, Greece. The city of Chios (Photo: T.S. Terkenli).

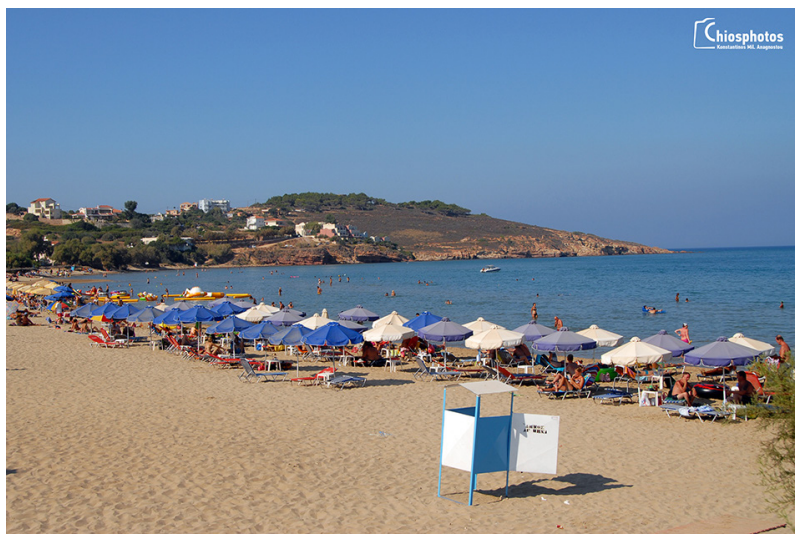

Fig. 5. Chios Island, Greece. The resort of Karfas (Source: http:/ / www.chiosonline.gr/karfas.asp).

inevitable limitations of our task, however, this research is undertaken as an exploratory investigation, leading to indicative findings, which will hopefully point to areas requiring further study and pave the ground for more in-depth, comprehensive and overarching research.

\section{Research design and method}

The research survey included 121 respondents (50 residents, 50 tourists and 21 tourism businesses/stakeholders) interviewed in Zwierzyniec, and 140 respondents (50 locals, 50 tourists and 40 tourism businesses/stakeholders) interviewed in Chios, with the aid of a structured questionnaire (shown on Table 3), by the researchers themselves, at the most highly visited locations and peak tourist periods. As for the visitors, purposive sampling was employed, while residents were interviewed using the door-todoor approach. Regarding the stakeholders, the sampling method was purposive non-probability sampling, as only owners/managers of tourism 
products were targeted, at the two surveyed sites. The tourists were asked about their conceptualization and understanding of the landscapes they visited in Zwierzyniec and Chios, at the end of their tourist visit, as well as about the significance of a number of landscape elements/properties (proposed by the researchers, on the basis of our tourist conceptual model, Fig. 1), and their possible contribution to the tourist landscape's definition. The same questions were posed to the other two categories of our case study samples, since tourism businesses/stakeholders are knowledgeable and hold valuable notions and opinions concerning their tourist landscapes, but also, in such small tourist destinations, the inhabitants of the respective host societies tend to be both highly sensitized to and often involved in the local tourist industry and its variable impacts (Terkenli et al. 2007). The survey in Poland took place in June-August 2012; in Greece, it was conducted during the tourist season of 2015 (April-October), when tourist businesses/hotels of the island are in operation and the destination receives the bulk of its tourists arrivals.

\section{Case study areas}

Zwierzyniec (3,400 inhabitants) is one of the most famous and popular tourist towns of the Lublin region, located in the Lubelskie Province of east-central Poland, in the physical-geographical macro-region of Roztocze. The tradition of Zwierzyniec as a holiday resort dates back to the $16^{\text {th }}$ century, when the countryside residence of the Zamoyski Family was established there. Nowadays, the attractiveness of Zwierzyniec is mainly based on its unique natural (forest, upland) landscape, located on the border of two different physical sub-regions - the loess Western Roztocze and the lime-sandy Middle Roztocze ones - as well as on the presence of the picturesque valleys of Wieprz and Świerszcz Rivers, the Echo bathing ponds, the artificial Lake Rudka Haff and the surrounding Kosobudy and Zwierzyniec forests (under protection as Roztoczański National Park, since 1974). A number of historic buildings erected by the Zamoyski family also contribute to tourist interest. Moreover, the tourist attractiveness of the area rests on its very favourable bioclimatic conditions for both summer and winter recreational activities. A number of the types of tourism that have been flourishing in and around the town are: leisure, nature, culture, educational, festival, sightseeing, and active tourism, such as hiking, cycling and kayaking (Skowronek et al. 2014). Short stays of several days tend to be the norm. 83 accommodation units $(\sim 2,000$ accommodation bed places) operate in Zwierzyniec, and the town is annually visited by approximately 200,000 tourists - mostly domestic (Świeca et al. 2015: 417).

Chios City and the town of Karfas were the survey sites of the respective case study on Chios Island, Greece, where most of the hotels and tourist agencies of the island are located. Chios is the fifth biggest Island of Greece, located in the Northeastern Aegean region, a seafarers' island with a long shipping tradition. In the last few decades, Chios has developed as a tourist destination, mostly because of its archaeological/historical/ecclesiastical monuments, crystal-clear-water beaches and other extraordinary natural beauty spots (not yet impacted much by tourism), as well as unique cultural traditions and celebrations (i.e. the Vrontados rocket war, at Easter). The castle of Chios is one of the main attractions of the city - one of the few inhabited castles in Greece - while other attractions include the archaeological, maritime, and other museums, the public garden and Korais' Library, etc. Chios Island features a great number of beaches - more than 90 officially recorded ones. Karfas is a small town/beach resort, $7 \mathrm{~km}$ south of Chios City and the most popular tourist destination of the island, due to its cosmopolitan beaches, clubs, restaurants, sports/leisure amenities and nightlife. It attracts mostly 3Ss (sea-sand-sun) and generally leisure tourism, international as well as domestic, and mostly couples and families.

\section{Questionnaire design and administration}

Following a pilot study $(\mathrm{N}=20)$, the questionnaire survey was conducted on a face-to-face basis, with a total of 241 landscape visitors, at the three survey sites (one in Poland and two in Greece). The questionnaire included questions pertaining to the interviewees' understanding and definitions of the tourist landscape and of its elements (their structure and constituent importance), besides, of course, the interviewees' personal demographic data. 
At the outset of the interview, both country cohorts were asked: Can the landscape of Zwierzyniec/ Chios be called a tourist landscape? Subsequently, they were asked to justify their opinions and point to three landscape elements/associations which determine its tourist nature. In the following part of the questionnaire, the respondents specified the influence on the attractiveness of the tourist landscape of 17 factors (elements), which had been selected by the authors on the basis of our preceding theoretical framework (Skowronek et al. 2014, 2018), culminating in the formulation of our model of tourist landscape constituent elements (Fig. 1). The list of 17 factors included aspects relating to:

- tourist attractions, such as climate, landform, waters, forests, green spaces in the towns/ villages, cleanliness and good environmental conditions, calm and quite surroundings, heritage/monuments, interesting new architecture, spatial layout of the town, local culture and events and

- tourist facilities/infrastructures and services, such as lodging and gastronomy, tourist paths/ trails, tourist information signs, residents' attitudes towards the tourists and hospitality.

The respondents made their assessments, with the aid of a Likert's scale, as follows: 5 - very high, 4 - high, 3 - neutral, 2 - low, and 1 - very low influence of the particular factor on the attractiveness of the tourist landscape. The opinions/perceptions/associations/values reported by our three interview groups (inhabitants, tourists, and businesses/stakeholders of the tourism industry) made it possible to ascertain how the tourist landscape and its constituent elements were perceived and understood by respondents from both countries. The findings, then, were analysed and manipulated with the aid of SPPS statistical tools (importance-based ratings with t-test and factor analysis); the results are presented and discussed in the next section of the paper.

\section{Findings and analysis}

\section{Demographic data}

The data collection involved 121 Polish and 140 Greek respondents. The demographic and socioeconomic survey results (Table 1) of this study indicate that males were a slight majority
Table 1. Respondents' demographic and socioeconomic profiles.

\begin{tabular}{|c|c|c|c|c|}
\hline \multirow{2}{*}{\multicolumn{2}{|c|}{ Characteristics }} & \multicolumn{2}{|c|}{ Nationality } & \multirow{3}{*}{$\begin{array}{c}\text { Total } \\
n=261 \\
132\end{array}$} \\
\hline & & \multirow{2}{*}{$\begin{array}{c}\begin{array}{c}\text { Polish } \\
(\mathrm{n}=121)\end{array} \\
65\end{array}$} & \multirow{2}{*}{$\begin{array}{c}\begin{array}{c}\text { Greek } \\
(\mathrm{n}=140)\end{array} \\
67\end{array}$} & \\
\hline Gender & Male & & & \\
\hline & & $54 \%$ & $48 \%$ & $51 \%$ \\
\hline & Female & 56 & 73 & 129 \\
\hline & & $46 \%$ & $52 \%$ & $49 \%$ \\
\hline \multicolumn{2}{|l|}{ Groups } & Polish & Greek & Total \\
\hline \multirow{2}{*}{\multicolumn{2}{|c|}{ Residents }} & 50 & 50 & 100 \\
\hline & & $41 \%$ & $36 \%$ & $38.3 \%$ \\
\hline \multirow{2}{*}{\multicolumn{2}{|c|}{ Tourists }} & 50 & 50 & 100 \\
\hline & & $41 \%$ & $36 \%$ & $38.3 \%$ \\
\hline \multirow{2}{*}{\multicolumn{2}{|c|}{ Business }} & 21 & 40 & 61 \\
\hline & & $18 \%$ & $28 \%$ & $23.4 \%$ \\
\hline \multicolumn{2}{|l|}{ Age } & Polish & Greek & Total \\
\hline \multicolumn{2}{|l|}{ Average } & 38.4 & 37.5 & 37.9 \\
\hline \multicolumn{2}{|l|}{ Min } & 19 & 19 & 19 \\
\hline \multicolumn{2}{|l|}{ Max } & 74 & 76 & 76 \\
\hline \multicolumn{2}{|l|}{ SD } & 13.3 & 13.7 & 13.5 \\
\hline
\end{tabular}

among the Polish respondents (54\%) over females, whereas the opposite held true for the Greek respondents (52\%).

As regards the cohort of the Polish respondents, both inhabitants and tourists each made up $41 \%$ of the total, while the representatives of the tourist industry and other tourism stakeholders made up $18 \%$ of the sample. In the case of the cohort of Greek respondents, inhabitants and tourists each constituted $36 \%$ of the total, while the various tourism stakeholders made up the remaining $28 \%$ of the sample.

The average age of the respondents was 37.9; however, the Polish average proved slightly higher at 38.4, while in Greece it was 37.5. The groups were equally diverse with respect to age, while the standard deviation in the group of Polish respondents was $\mathrm{SD}=13.3$ and that of Greek respondents was SD=13.7.

\section{Understanding and conceptualization of tourist landscape}

The survey started by asking the respondents: Can the landscape of Zwierzyniec/Chios be called a tourist landscape?, to which the authors received overwhelmingly positive answers (Table 2).

The analysis of the findings showed that 95\% of the total number of respondents provided a positive response (95/100 residents; 89/100 tourists, and 60/61 tourist business). This finding is in 
Table 2. Responses to the question: Can the landscape of Zwierzyniec/Chios be called a tourist landscape?

\begin{tabular}{|c|c|c|c|c|c|c|c|c|c|c|c|c|}
\hline \multirow{2}{*}{ Groups } & \multicolumn{4}{|c|}{ Polish } & \multicolumn{4}{|c|}{ Greek } & \multicolumn{4}{|c|}{ Total } \\
\hline & Yes & $\%$ & No & $\%$ & Yes & $\%$ & No & $\%$ & Yes & $\%$ & No & $\%$ \\
\hline Residents & 48 & 96.0 & 2 & 4 & 47 & 94.0 & 3 & 6.0 & 95 & 95.0 & 5 & 5.0 \\
\hline Tourists & 47 & 94.0 & 3 & 6 & 42 & 84.0 & 8 & 16.0 & 89 & 89.0 & 11 & 11.0 \\
\hline Businesses & 21 & 100.0 & 0 & 0 & 39 & 97.5 & 1 & 2.5 & 60 & 98.0 & 1 & 2.0 \\
\hline
\end{tabular}

accordance with the users' visit motives - and the main economic functions and services provided by the surveyed sites. These results also confirm the appropriateness of the survey areas selected for this study of tourist landscape structure.

Next, the respondents were asked to justify their statements; the various answers obtained were decodified and grouped into three main groups, in accordance with our theoretical framework, as presented in the previous section (Skowronek et al. 2014):

- tourist attractions - including environmental and cultural resources/values (particularly historical sites), etc.

- tourist amenities/services - statements concerning tourism infrastructure and

- presence of tourists - emotions, impressions, etc. associated with the landscape.

Summing up, based on our findings, it seems clear that our respondents overwhelmingly considered the surveyed landscapes as tourist landscapes, readily associating them with the functions that they seemed to serve, while catering to their own motives. The respondents justified their responses mostly based on the attractions these landscapes have to offer, and especially those connected to the natural dimension of the landscape. This outcome accords with long-standing, broadly held lay conceptualizations of landscape, where its natural dimension predominates (Bastian et al. 2015). The outcome also accords with both the principal and the more specific tourism motives in our case studies, all of which place an emphasis on nature - whether they refer to seaside tourism (3Ss), or upland tourism (forests, national parks, ponds, etc.).

\section{Contribution of landscape features to tourists' conceptualization of tourist landscape}

The following stage of the research concerned the contribution of our selected 17 elements of the landscapes under study to their

Table 3. Respondents' assessment of the contribution of selected elements of the landscape to its attractiveness as a tourist landscape ( $\mathrm{R}$ - residents, $\mathrm{T}$ - tourists, B - business respondents).

\begin{tabular}{|c|c|c|c|c|c|c|c|c|c|}
\hline \multirow{3}{*}{ Variables } & \multirow{2}{*}{$\begin{array}{c}\text { Total } \\
(\mathrm{N}=261)\end{array}$} & \multicolumn{4}{|c|}{ Polish $(\mathrm{N}=121)$} & \multicolumn{4}{|c|}{ Greek $(\mathrm{N}=140)$} \\
\hline & & Total & $\mathrm{R}$ & $\mathrm{T}$ & B & Total & $\mathrm{R}$ & $\mathrm{T}$ & B \\
\hline & \multicolumn{9}{|c|}{ Average score } \\
\hline Climate & 4.0 & 4.1 & 4.1 & 4.2 & 4.2 & 4.0 & 4.1 & 3.7 & 4.1 \\
\hline Landforms & 3.7 & 4.3 & 4.4 & 4.3 & 4.1 & 3.2 & 3.2 & 3.4 & 2.9 \\
\hline Water elements & 4.1 & 4.4 & 4.5 & 4.4 & 4.3 & 3.9 & 3.7 & 4.1 & 3.9 \\
\hline Forests & 4.0 & 4.6 & 4.6 & 4.5 & 4.4 & 3.5 & 3.4 & 3.6 & 3.4 \\
\hline Urban green spaces & 3.9 & 4.2 & 4.3 & 4.3 & 4.0 & 3.6 & 3.3 & 3.7 & 4.0 \\
\hline Cleanliness \& good environmental conditions & 4.2 & 4.3 & 4.4 & 4.2 & 4.3 & 4.1 & 3.8 & 4.2 & 4.4 \\
\hline Calm/quiet surroundings & 4.2 & 4.3 & 4.4 & 4.4 & 4.1 & 4.0 & 3.9 & 3.9 & 4.3 \\
\hline Heritage \& monuments & 4.1 & 4.1 & 4.1 & 4.1 & 4.0 & 4.2 & 4.2 & 4.1 & 4.2 \\
\hline Interesting contemporary architecture & 3.2 & 3.1 & 3.1 & 3.1 & 3.1 & 3.2 & 3.2 & 3.3 & 3.2 \\
\hline Spatial town layout & 3.4 & 3.3 & 3.3 & 3.3 & 3.5 & 3.5 & 3.2 & 3.7 & 3.5 \\
\hline Local culture & 4.1 & 4.2 & 4.3 & 4.1 & 4.0 & 4.0 & 3.9 & 4.0 & 4.2 \\
\hline Events & 3.6 & 3.8 & 3.6 & 3.8 & 4.2 & 3.4 & 3.5 & 3.3 & 3.5 \\
\hline Lodging \& gastronomy & 4.0 & 4.0 & 4.0 & 4.0 & 4.1 & 4.0 & 3.9 & 3.8 & 4.2 \\
\hline Tourist paths/trails & 4.3 & 4.5 & 4.5 & 4.5 & 4.4 & 4.1 & 4.2 & 4.0 & 4.0 \\
\hline Tourist information signage & 3.9 & 4.1 & 4.1 & 4.0 & 4.1 & 3.8 & 3.5 & 4.0 & 4.0 \\
\hline Presence of tourists & 3.7 & 3.9 & 4.1 & 3.8 & 4.0 & 3.4 & 3.5 & 3.3 & 3.6 \\
\hline Residents' attitude \& hospitality & 4.3 & 4.2 & 4.1 & 4.2 & 4.4 & 4.3 & 4.0 & 4.5 & 4.6 \\
\hline
\end{tabular}


attractiveness as tourist landscapes. Respondents made their assessments with the aid of a 5-grade Likert's scale. For the second question, then, basic statistical analysis was performed, in order to produce importance-based ratings for these landscape features, a) in total, b) in cross-country comparison, and c) for each category of respondents (residents, tourists and tourism businesses/ stakeholders) separately (Table 3).

Data analysis of these assessments showed that, for the majority of respondents, the elements that seemed to affect most the attractiveness of a tourist landscape were the social factor (the human factor, i.e. residents' attitude and hospitality), but also the physical/natural environment, both in terms of its state and in terms of its development for tourism purposes (tourist paths and trails, calmness and quietness, as well as cleanliness and good environmental conditions). These latter findings may be connected with the landscape quality of a given destination, and certainly constitute an important point of consideration for tourism supply-side providers and organizers, in both locations. After all, natural features (climate, waters, forests), cultural ones (monuments, local culture), lodging and gastronomy (services, infrastructure) were all valued highly.

As concerns perceived attractiveness of the tourist landscape, respondents from Poland valued most highly the presence of forests, footpaths, cycle lanes, didactic trails, as well as running water and ponds. The lowest importance was attributed to elements such as interesting contemporary architecture, spatial layout of the town, and events. Their responses confirmed their acknowledgment of the destination's leading tourist attractions that they used; the remaining elements were indifferent to them. In Zwierzyniec, there are no examples of interesting contemporary architecture, while events, though increasingly popular, are rare.

In the same context of the attractiveness of the tourist landscape, respondents from Greece valued most highly residents' attitude and hospitality (a long-standing and well-established lure for Greek tourism), and also heritage/monuments, as well as cleanness and good environmental conditions and, finally, tourist paths and trails. In their views, landforms and interesting contemporary architecture are least important, since, here, apparently, the main visit motives were leisure and rest/relaxation, rather than more specific pursuits of natural or cultural destination particularities.

Assessments of the contribution of particular elements to the attractiveness of these tourist landscapes were mostly similar among respondents from both countries. The greatest discrepancies concerned assessments of certain natural and physical factors (assessed more highly by Polish respondents), such as the presence of water, forests, greenery in towns and villages, and tourist information signs. All of the latter may be viewed as essential components of the specific tourist experience these visitors were pursuing in Zwierzyniec, in the first place.

\section{Factor analysis}

To identify any underlying interrelations between these tourist landscape's attributes, a principal factor analysis, using Quartimax rotation, was performed. As a result, four important factor solutions were derived, with final communalities higher than 0.40 (Table 4).

The KMO score was 62 and Barlett's test $\left(\right.$ chi $\left.^{2}=1168 ; p<0.01\right)$ of sphericity was statistically significant at 0.01 levels. The reliability coefficient range of Cronhach's alpha test was from 0.76 (F1) to $0.54(\mathrm{~F}-4)$, indicating that variables were

Table 4. Kaiser-Mayer-Olkin and Bartlett tests.

KMO measure of sample compatibility $\quad 0.800$

\begin{tabular}{l|c|c|} 
Bartlett's sphericity & Chi-square estimation & 1168.029 \\
\cline { 2 - 3 } & & 136
\end{tabular}
test

Significance

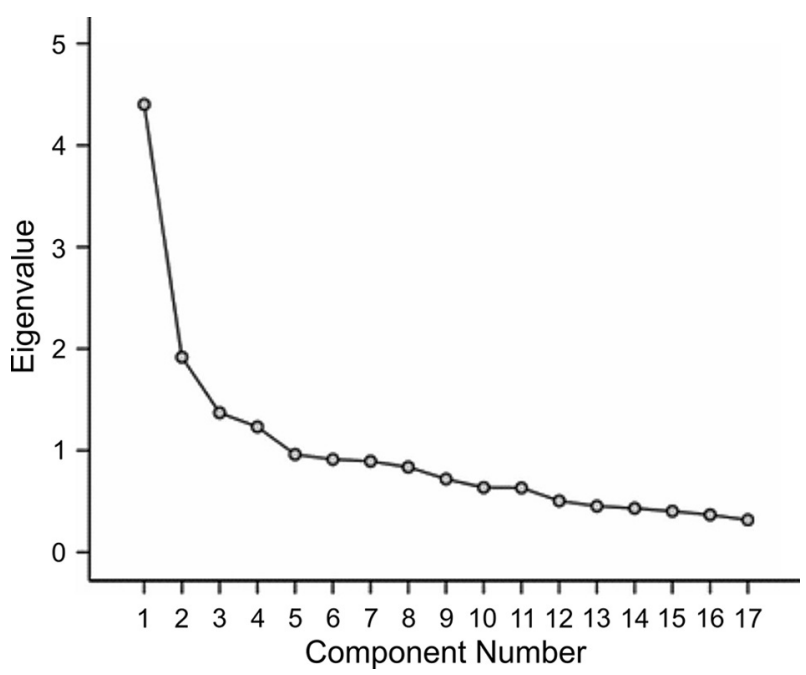

Fig. 6. The scree test. 
internally consistent and showing a strong correlation between retained factors and variables. Again, each of the derived factors was labelled based upon the characteristics and nature of the variables from which they were derived. The four factors, labelled (F-1) Services \& Quality of Stay, (F-2) Nature, (F-3) Culture and (F-4) Elements of Tourism Development, were featured and confirmed with the aid of the method of determination of the number of common factors - a scree test, which is based on the visual analysis of the diagram of eigenvalue characterizing individual components (Fig. 6).

Table 5. Results of Principal Factor Analysis.

\begin{tabular}{|c|c|c|c|c|c|}
\hline $\begin{array}{c}\text { Latent } \\
\text { Constructs }\end{array}$ & \multicolumn{4}{|c|}{ Factor Loading } & $\begin{array}{l}\text { Reliability } \\
\text { coefficient } \\
\text { (Alfa } \\
\text { Cronbach) }\end{array}$ \\
\hline $\begin{array}{l}\text { (F-1) Services and } \\
\text { Quality of Stay }\end{array}$ & & & & & 0.775 \\
\hline $\begin{array}{l}\text { Cleanliness \& } \\
\text { good environ- } \\
\text { mental conditions }\end{array}$ & 0.762 & & & & \\
\hline $\begin{array}{l}\text { Tourist informa- } \\
\text { tion signage }\end{array}$ & 0.739 & & & & \\
\hline $\begin{array}{l}\text { Residents' atti- } \\
\text { tude \& hospi- } \\
\text { tality }\end{array}$ & 0.647 & & & & \\
\hline $\begin{array}{l}\text { Urban green } \\
\text { spaces }\end{array}$ & 0.601 & & & & \\
\hline $\begin{array}{l}\text { Lodging \& gas- } \\
\text { tronomy }\end{array}$ & 0.566 & & & & \\
\hline $\begin{array}{l}\text { Tourist paths/ } \\
\text { trails }\end{array}$ & 0.507 & & & & \\
\hline $\begin{array}{l}\text { Calm/quiet sur- } \\
\text { roundings }\end{array}$ & 0.504 & & & & \\
\hline (F-2) Nature & & & & & 0.685 \\
\hline Landforms & & 0.824 & & & \\
\hline Water elements & & 0.669 & & & \\
\hline Forests & & 0.659 & & & \\
\hline Climate & & 0.409 & & & \\
\hline (F-3) Culture & & & & & 0.573 \\
\hline $\begin{array}{l}\text { Heritage \& mon- } \\
\text { uments }\end{array}$ & & & & 0.765 & \\
\hline Events & & & & 0.419 & \\
\hline Local culture & & & & 0.417 & \\
\hline $\begin{array}{l}\text { (F-4) Elements of } \\
\text { Tourism Devel- } \\
\text { opment }\end{array}$ & & & & & 0.542 \\
\hline $\begin{array}{l}\text { Interesting new } \\
\text { architecture }\end{array}$ & & & 0.703 & & \\
\hline $\begin{array}{l}\text { Spatial town } \\
\text { layout }\end{array}$ & & & 0.681 & & \\
\hline $\begin{array}{l}\text { Presence of } \\
\text { tourists }\end{array}$ & & & 0.448 & & \\
\hline
\end{tabular}

The first factor (F-1) corresponds to seven variables (Table 5), and is explained by $27.46 \%$ of variance. The second factor (F-2) encompasses four variables, grouped under the factor of Nature, explained $10.73 \%$ of variance, in the factor analysis. The third factor (F-3) named Culture and the final factor (F-4) composed of three variables. Both F-3 and F-4 can be explained at $6.86 \%$ and $8.14 \%$ respectively, for variance in the model. Next, we compared respondents' answers on the grounds of country case study, using the Student t-test, to compare the mean responses for the two independent groups (Table 6).

The analysis showed Polish respondents rating 'services \& quality of stay' higher than Greek respondents (respectively $M=29.6$ and 27.9), by a statistically significant difference $\left(\mathrm{t}_{(257)}=3.288\right.$; $p<0,05)$. Polish respondents also assessed the 'nature' component higher than Greeks - respectively $\mathrm{M}=17.5$ and 14.5 - by a statistically significant difference $\left(\mathrm{t}_{(257)}=10,566 ; p<0,01\right)$. Likewise, for 'culture', the findings were respectively $\mathrm{M}=12$ and 11.4, with a statistically significant difference $\left(t_{(259)}=1,970 ; p \leq 0,5\right)$. No significant differences were detected between Polish and Greeks, for the factor 'elements of tourism development'. Generally speaking, these differences are not great, indicating only a slightly higher evaluation of certain aspects and features of the destination landscape by the Polish interviewees. This difference may be due to a variety of factors: higher environmental awareness and sensitivity towards their own land (whereas tourists in Chios came from a variety of places and also from abroad), and/or higher tourist overload and concentration in Chios, often affecting the quality of tourist experiences, typical of the situation on Greek island tourist destinations, in high season.

The next step in our statistical analysis consisted of checking whether there were any significant differences among groupings of landscape elements, by group of respondents (inhabitants, tourists and stakeholders of the tourism industry). Owing to the fact that these groups were comprised of different numbers of respondents, the analyses were done by means of the Kruskal Wallis non-parameter test (Table 7).

The test revealed no significant differences between any of the respondent groups (inhabitants, tourists, and stakeholders/tourist industry) for 
Table 6. Descriptive statistics of t-test for independents samples, by country $(t-t$-test, $p$ - significance at the 0.05 level).

\begin{tabular}{|l|c|c|c|c|c|c|}
\hline \multirow{2}{*}{ Factors } & \multicolumn{2}{|c|}{ Poland (N=121) } & \multicolumn{2}{c|}{ Greece (N=140) } & \multirow{2}{*}{$t$} & \multirow{2}{*}{$p$} \\
\cline { 2 - 7 } & $\mathrm{M}$ & $\mathrm{SD}$ & $\mathrm{M}$ & $\mathrm{SD}$ & & \\
\hline Services and quality of stay & 29.63 & 3.70 & 27.92 & 4.68 & 3.288 & 0.001 \\
\hline Nature & 17.47 & 1.91 & 14.50 & 2.62 & 10.556 & 0.000 \\
\hline Culture & 12.04 & 2.22 & 11.44 & 2.69 & 1.970 & 0.050 \\
\hline Elements of tourism development & 10.28 & 2.31 & 10.12 & 2.43 & 0.540 & 0.589 \\
\hline
\end{tabular}

Table 7. Statistical analysis, using the Kruskal Wallis test, by respondent group and by country, for the total respondent sample $(\mathrm{N}=261)$.

\begin{tabular}{|l|c|c|c|c|c|c|c|c|c|}
\hline \multirow{2}{*}{\multicolumn{1}{|c|}{ Factors }} & \multicolumn{3}{c|}{ Total $(\mathrm{N}=261)$} & \multicolumn{3}{c|}{ Poland (N=121) } & \multicolumn{3}{c|}{ Greece (N=140) } \\
\cline { 2 - 10 } & $\mathrm{chi}^{2}$ & $\mathrm{df}$ & $p$ & $\mathrm{chi}^{2}$ & $\mathrm{df}$ & $p$ & chi $^{2}$ & $\mathrm{df}^{2}$ & $p$ \\
\hline Services and quality of stay & 4.354 & 2 & 0.113 & 0.003 & 2 & 0.998 & 10.583 & 2 & 0.005 \\
\hline Nature & 5.080 & 2 & 0.079 & 1.371 & 2 & 0.504 & 1.409 & 2 & 0.494 \\
\hline Culture & 1.235 & 2 & 0.539 & 0.994 & 2 & 0.608 & 1.563 & 2 & 0.458 \\
\hline Elements of tourism development & 0.768 & 2 & 0.681 & 0.263 & 2 & 0.877 & 1.023 & 2 & 0.599 \\
\hline
\end{tabular}
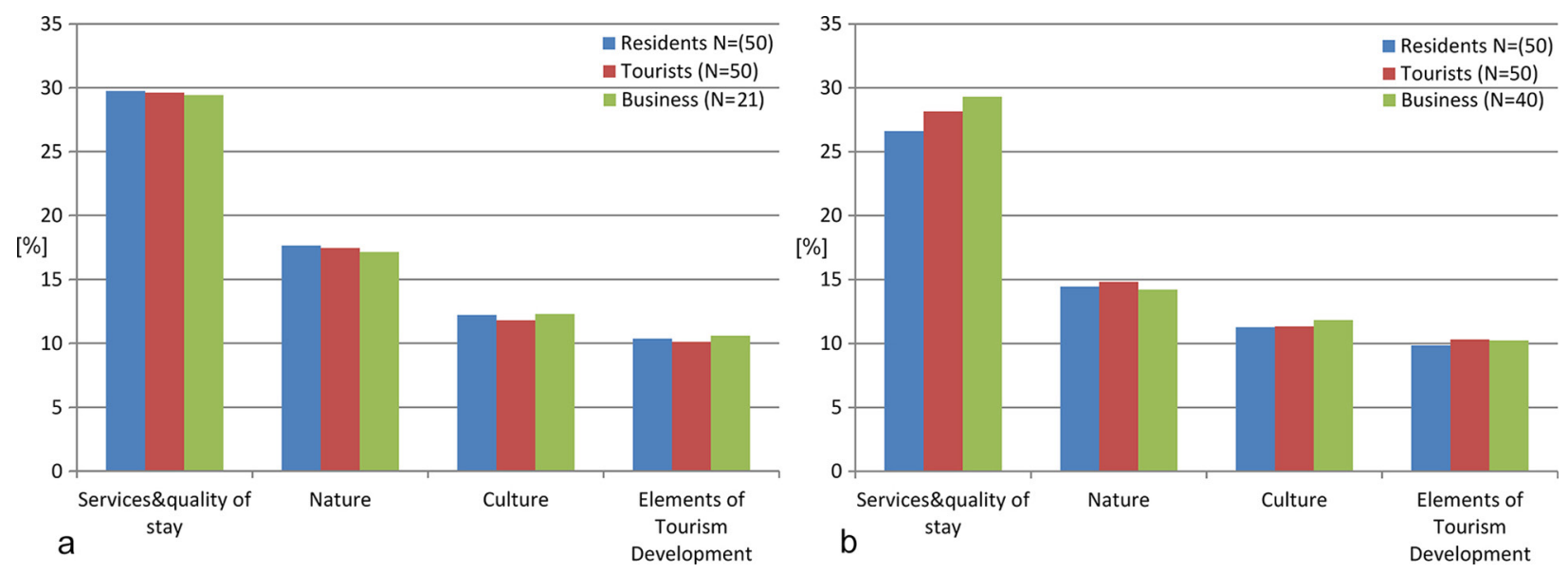

Fig. 7. A comparison of average assessments of landscape elements, by respondent group, for the cohort of Polish (a) and Greek (b) respondents.

the whole sample (Poles and Greeks), as well as for the Polish cohort separately (Fig. 7 a).

However, statistical differences emerged between at least two respondent groups, in their assessment of the infrastructure element of the tourist landscape, in the Greek respondent cohort $\left(\mathrm{chi}_{(2)}^{2}=10,583 ; p<0.05\right)$. The respondents of the inhabitants cohort offered considerably lower assessments for the services and quality of stay factor than those of the business/tourist stakeholders cohort (respectively $M=26.6$ and $M=29.3$ ) (Fig. 7 b).

Obviously, this finding may be attributed to the very different - and often conflictual - interests and stakes at play in the tourism industry and local tourism development, between the two sides - the locals and the tourism stakeholders.

\section{Alignment of analytical findings with theoretical framework}

Our research aimed at elucidating the definition and conceptualization of tourist landscapes and their constituent elements. We applied our theoretical premises (model of three tourist landscape constituent element groupings) to a cross-cultural research survey and our findings were used in order to verify our initial conceptualization of tourist landscapes and their main element categories. The analysis of the stated perceptions and element values provided by our respondents made it possible to ascertain the extent to which the analytical outcomes aligned with the authors' conceptualization of the tourist landscape and its constituent elements. 
Comparing findings by country, the outcome of our data analysis indicated that respondents in both country cases conceptually acknowledged the existence and functioning of the tourist landscape and were able to identify its features/ constituent elements. Justifying the existence of the tourist landscapes of their destinations, they provided examples of these landscapes' features, which allowed for grouping them together in three sets (groupings) of tourist landscape constituent elements: tourist attractions, tourism facilities/services/infrastructure and aspects of tourism-induced development (connected with the presence there of tourists). This group proved to be consistent with the proposed theoretical framework of this study, culminating in the construction of the relevant model (Fig. 1).

Of the 17 tourist landscape constituent elements identified by the authors and assessed by the respondents during the interview surveys, only two - interesting contemporary architecture and the spatial layout of the destination town were considered unconnected with the tourist landscape. This statistical outcome may be due to the specific features of the tourist destinations under study and/or to the socio-cultural characteristics of the respondents and their particular perceptions. This fact suggests the need for further study of such or similar research questions, also in other types of tourist destinations, bearing variable tourist landscape features and resources (e.g. cultural tourism destinations or various mild/alternative/ special-interest tourist destinations), where architectural aspects of the visited landscapes and urban design may hold more specialized interest for certain categories of special-purpose tourists.

Assessment of the contribution of selected landscape elements to its attractiveness as a tourist landscape was mostly similar, in both country cases. However, it was also possible to ascertain the link between these assessments and the specificity of the types of tourism at the studied tourist destinations (active and sightseeing tourism in Poland, vs 3S, leisure and sightseeing tourism in Greece). The degree of tourism development (higher in the Greek case study, lower in the Polish case) also proved to be important in these assessments. Irrespective of the country of tourists' origin, our interviewees responded that the tourist landscape elements most important to them related to the provided services and quality of stay (e.g. cleanliness and good environmental conditions, local residents and hospitality, calm and quite conditions, urban green spaces, lodging and gastronomy, tourism information signage and paths/trails), as well as the presence of natural and cultural attractions. Such findings constitute significant information for those responsible for tourism development and destination management and marketing. Furthermore, we would anticipate that, at mass tourism destinations, different tourist landscape users groups would be more likely to represent variable, different, and even conflictual, opinions and perceptions of these landscapes and their constituent elements - also worthy of in-depth investigation.

Therefore, the overall process of landscape planning and stewardship emerges as a most important, indeed crucial, aspect of appropriate, integrative and sustainable tourist destination management. In the long-term perspective, only those destinations able to offer tourists and residents a high enough quality of life or stay, in any given context, will remain competitive in the tourism industry.

\section{Discussion and conclusions}

The aim of the present work was to initiate a discussion concerning the term tourist landscape, namely its definition and constitution/operationalization, and to do so in on a cross-cultural basis. Existing definitions contain insights from many disciplines (e.g. geography, landscape ecology, sociology, economics), creating the possibility of conducting interdisciplinary research. However, such research is so far in its initial stages, attempting relevant inroads, at an exploratory level. Nonetheless, such a bibliographical overview was very helpful in elucidating our research questions, at the outset of our study, and in confirming its theoretical underpinnings, at the end of our study, after data analysis and the drawing of our final results.

Based on our findings so far, we suggest that a tourist landscape is a type of cultural landscape, functionally related to tourists and tourism activity; its attributes may be organized in three groupings: tourist attractions, tourism facilities/ services, and the presence of tourists (Fig. 1). Our survey results, though inevitably only indicative 
- due to the scale and extent of this study - confirm the authors' conceptualization of the tourist landscape, as incorporating not only a) objective physical and cultural landscape elements (as poles of tourist attraction) and b) various aspects of tourism infrastructure and amenities, but also c) tourists' own perceptions, emotions and mind states, vis-à-vis the visited landscapes-stemming and resulting from the presence and use of the tourists themselves in them.

Tourist landscapes vary as do their definitions. They are affected by subjective evaluation and conceptualization by all groups involved, in conjunction with their perceptions, feelings and expectations, thus also ensuring their continuous transformation. However, in our study, we found surprisingly similar understandings of tourist landscapes, between the two countries, despite their two very different types of tourist landscapes (upland, seaside), pointing perhaps to the international - if not global - standards and expectations of the present-day tourism industry, and the need for the replication of such studies also in non-European tourism contexts. Of particular note, here is the significance of the type of tourism: our two case studies offered mainly to milder forms of tourism, as opposed to mass, organized types of tourism development. In our study, then, services and quality of stay specially emerged as a foremost consideration among tourists, at both destinations.

In the minds of the respondents, natural attractions appeared to be the most significant element in the constitution of these landscapes as tourist landscapes; this finding was responsible also for the small difference between responses from Poland vs Greece. Natural scenery has long been established as a major aspect of nature-based tourism (Daniel 2001, Scolozzi et al. 2015), while perceived visual landscape quality increases with the degree of wildness perceived in the landscape, the percentage of plant cover and the amount of water present in the landscape (Arriaza et al. 2004). However, it should be conceded that different results may be obtained in different tourist destinations, depending on a series of physical, social and cultural variables under study.

Enhancing the understanding of tourist landscapes ought to serve the purpose of organising knowledge resources, towards a fuller and more in-depth conceptualization of such landscapes, as well as of their shaping mechanisms, their structure and constitution, and the ways in which they respond to the variety of impacts that the tourism industry imparts on them. More significantly, it also ought to guide tourism and landscape planning and management, by ascertaining both the conditions and the desired directions in future stewardship of landscape resources and values beneficial to tourism and to the landscape, in a sustainable, long-term perspective.

In conclusion, this study has relevant implications for landscape professionals concerned with the planning, design and management of developing tourist areas, but also for the whole range of tourism stakeholders, towards the development of more sustainable types and experiences of tourism, on the basis of local resource preservation and enhancement. However, in order to gain further and more complete empirical insights for purposes of fine-tuning tourist landscape definitions and conceptualizations - both from interdisciplinary and from cross-cultural perspectives - further research and its empirical replications are necessary, employing accordingly operationalized terms, in diverse fieldwork settings, with larger sample groups, different tourism development models, as well as applications to various types of tourist landscapes.

\section{Acknowledgments}

This research was in part financially supported by the Faculty of Earth Sciences and Spatial Management of the Maria Curie-Skłodowska University in Lublin, Poland.

\section{Author's contribution}

TST $35 \%$, ES $30 \%$, AT $20 \%$, NK $15 \%$.

\section{References}

Adevi A. A., Grahn P., 2012. Preferences for landscape: a matter of cultural determinants or innate reflexes that point to our evolutionary background? Landscape Research 37(1): 27-49. DOI: 10.1080/01426397.2011.576884.

Antrop M., 1998. Landscape Change: Plan or Chaos? Landscape and Urban Planning 41(3-4): 155-161. DOI: 10.1016/ S0169-2046(98)00068-1.

Arriaza M., Cañas-Ortega J. F., Cañas-Madueño J. A., RuizAviles P., 2004. Assessing the visual quality of rural landscapes. Landscape and Urban Planning 69: 115-125. DOI:10.1016/j.landurbplan.2003.10.029. 
Bastian O., Stein C., Lupp G., Behrens J., 2015. The appreciation of nature and landscape by tourism service providers and visitors in the Ore Mountains (Germany). Landscape Online 41: 1-23. DOI 10.3097/LO.201541.

Cartier C., Lew A. A. (eds.), 2005. Seductions of Place: Geographical Perspectives on Globalization and Touristed Landscapes. Routledge, London.

Chrenka B., Ira V., 2011. Transformation of tourist landscapes in mountain areas: Case studies from Slovakia. Human Geographies - Journal of Studies and Research in $\mathrm{Hu}$ man Geography 5(2): 13-20. DOI: 10.5719/hgeo.2011.52.13.

Chronis A., Hampton R. D., 2008. Consuming the authentic Gettysburg: How a tourist landscape becomes an authentic experience. Journal of Consumer Behaviour 7(2): 111-126. DOI: $10.1002 / \mathrm{cb} .241$.

Conrad E., Christie M., Fazey I., 2011. Understanding public perceptions of landscape: A case study from Gozo, Malta. Applied Geography 31(1): 159-170. DOI: 10.1016/j. apgeog.2010.03.009.

Coccossis H., Tsartas P., 2001. Sustainable Tourism Development and the Environment (in Greek). Kritiki, Athens.

Daniel T. C., 2001. Whither scenic beauty? Visual landscape quality assessment in the 21st century. Landscape and $U r-$ ban Planning 54(1): 267-281.

Dietvorst A., 1996. Tourist landscapes: Accelerating transformations. In: S. Scraton (ed.), Leisure, Time and Space: Meanings and Values in People's Lives. Brighton, LSA Publication 57: 13-24.

Fyhri A., Jacobsen J. K. S., Tømmervik, H., 2009. Tourists' landscape perceptions and preferences in a Scandinavian coastal region. Landscape and Urban Planning 91(4): 202 211. DOI: 10.1016/j.landurbplan.2009.01.002.

Gkoltsiou K., Terkenli T. S., 2012. An interdisciplinary analysis of tourist landscape structure. Tourismos 7(2): 145-164.

Kowalczyk A., Derek M., 2010. Zagospodarowanie turystyczne. Wydawnictwo Naukowe PWN, Warszawa.

Krzymowska-Kostrowicka A., 1999. Kulturowe uwarunkowania oceny i waloryzacji krajobrazów turystyczno-rekreacyjnych. Geoekologiczne podstawy badania i planowania krajobrazu rekreacyjnego. Problemy Ekologii Krajobrazu 5: 11-16.

Kulczyk S., 2013. Krajobraz i turystyka. O wzajemnych relacjach. WGiSR UW, Warszawa.

Jafari J., 1982. The tourism market basket of goods and services: the components and nature of tourism. In: T. V. Singh, J. Kaur, D.P. Singh (eds.), Studies in tourism, wildlife, parks, conservation. New Delhi, Metropolitan Book Co. Pvt. Ltd: 1-12.

Lozato-Giotart J.P., 1993. Géographie du tourisme. Masson, Paris.

Löfgren O., 1999. On Holiday: a History of Vacationing. University of California Press, Berkeley.

Mikulec J., 2011. Landscape and tourism potential in the protected landscape areas. Agricultural Economics 57(6): 272-278.

Norton A., 1996. Experiencing nature: the reproduction of environmental discourse through safari tourism in East Africa. Geoforum 27(3): 355-373. DOI: 10.1016/S00167185(96)00021-8
Myga-Piątek U., 2012. Krajobrazy kulturowe. Aspekty ewolucyjne i typologiczne. Pracownia Komputerowa Jacka Skalmierskiego, Katowice.

Pearce, D. G., 1995. Tourism Today: A Geographical Analysis. Longman Scientific \& Technical, New York.

Richling, A., 2010. O krajobrazie raz jeszcze: Czy istnieją krajobrazy rekreacyjne. Problemy Ekologii Krajobrazu 27: 341-344.

Rojek C., Urry J., 1997. Touring Cultures: Transformations of Travel and Theory. Routledge, London.

Roovers P., Hermy M., Gulinck H., 2002. Visitor profile, perceptions and expectations in forests from a gradient of increasing urbanisation in central Belgium. Landscape and Urban Planning 59(3): 129-145.

Scolozzi R., Schirpke U., Detassis C., Sabah A., Gretter A., 2014. Mapping Alpine Landscape Values and Related Threats as Perceived by Tourists, Landscape Research 40(4): 3-17. DOI: 10.1080/01426397.2014.902921.

Skowronek E., Jóźwik M., Tucki A. 2014. Struktura i percepcja krajobrazu turystycznego Zwierzyńca. Barometr Regionalny 12(4): 61-70.

Skowronek E., Tucki A., Huijbens E., Jóźwik M. 2018. What is the tourist landscape? Aspects and features of the concept. Acta geographica Slovenica 58(2): 73-85. DOI: 10.3986/AGS.3311.

Świeca A., Brzezińska-Wójcik T., Skowronek E., Krukowska R., Tucki A., Grabowski T., Malska M., Zinko J., Brusak V., Pandiak I., Shevchuk O., 2015. Turystyka na Roztoczu. In: T. Grabowski, M. Harasimiuk, B. M. Kaszewski, Y. Kravchuk, B. Lorens, Z. Michalczyk, O. Shabliy (eds.), Roztocze - przyroda i człowiek. RPN, Zwierzyniec.

Terkenli T. S., 2000. Landscapes of tourism: a cultural geographical perspective. In: H. Briassoulis, J. van der Straaten (eds.), Tourism and the Environment: Regional, Economic, Cultural and Policy Issues. Kluwer Academic Publishers, Dordrecht: 179-202.

Terkenli T. S., 2002. Landscapes of tourism: towards a global cultural economy of space? Tourism Geographies 4 (3): 227-254. DOI: 10.1080/14616680210147409.

Terkenli T. S., Bellas M. L., Dudley-Jenkins L., 2007. Tourism impacts on local life: socio-cultural continuity and change in Crete. Aegean Geographical Journal 16(1-2): 37-52.

Terkenli T. S., 2014. Landscapes of Tourism. In: A. A. Lew, M. C. Hall, and A. M. Williams (eds.), The Wiley-Blackwell Companion to Tourism. First Edition, John Wiley \& Sons. Oxford.

Terkenli T., Castiglioni B., Cisani M., 2019. The challenge of tourism in terraced landscapes. In: M. Varotto, L. Bonardi, P. Tarolli, M. Agnoletti (eds.), World terraced landscapes: history, environment, quality of life. Springer, Dordrecht (forthcoming).

Urry J., 1995. Consuming Places. Routledge, London.

Włodarczyk B., 2009a. Przestrzeń turystyczna. Istota, koncepcje, determinanty rozwoju. Wydawnictwo Uniwersytetu Łódzkiego, Łódź.

Włodarczyk B., 2009b. Krajobrazy przestrzeni turystycznej. Turyzm 19(1-2): 89-97.

Xiaobo Su, 2010. The Imagination of Place and Tourism Consumption: A Case Study of Lijiang Ancient Town, China. Tourism Geographies 12(3): 412-434. 